\title{
Anti-Malarial Plants of Jonai, India: an Ethnobotanical Approach
}

\author{
Tonlong WANGPAN ${ }^{1}$, Luk Bahadur CHETRY ${ }^{2 *}$, Jambey TSERING ${ }^{1}$, Tapi TAKA ${ }^{1}$, \\ Sumpam TANGJANG ${ }^{1}$
}

\author{
${ }^{1}$ Rajiv Gandhi University, Department ofBotany, Rono Hills,Doimukh 791112,ArunachalPradesh, India; twangpan@gmail.com;jamserng@gmail.com; \\ aka7daniel@gmail.com;sumpam@gmail.com \\ ${ }^{2}$ Rajiv Gandhi University, Department of Zoology, Rono Hills, Doimukh 791112, Arunachal Pradesh, India; lukbahadurchetry@gmail.com (*correspondingauthor)
}

\begin{abstract}
North-East India represents a unique ecosystem with treasured medicinal plant wealth closely related with Folk medicines. A large number of plants having medicinal properties and their folk uses have remained confined to the natives of this region. The tribal community of Jonai, Assam was explored to expose the indigenous herbal remedy for malaria. Sixteen antimalarial plants belonging to 13 families were reported. The analysis revealed highest fidelity level (FL) value for Ajuga integrifolia (100\%) followed by Ricinus communis (94\%), Alstonia scholaris (88\%), Oroxylum indicum (86\%) and Achyranthes aspera (82\%). The percentage of respondent's knowledge (PRK) about anti-malarial plants showed Alstonia scholaris as the most commonly known antimalarial species (53\%) within this region. Preference ranking (PR) unveiled eight species to be very effective against malarial parasite, which includes Allium sativum, Artemisia indica, Azadirachta indica, Carica papaya, Clerodendrum glandulosum, Ocimum tenuiflorum, Oroxylum indicum, Piper longum and Piper nigrum. All medicine preparations are made using water as the medium and are orally administered in the form of crude extract, powder, juice and decoction. Overall analysis suggested Ajuga integrifolia, Achyranthes aspera, Alstonia scholaris, Artemisia indica, Oroxylum indicum and Ricinus communis to be used for the development of novel, economical, effective and ecofriendly herbal formulations for healthcare management.
\end{abstract}

Keywords: Assam, ethnopharmacology, fidelity level, medicinal plant, preference ranking

\section{Introduction}

Malaria is the most prevalent disease that kills more than one million people every year, with as many as 300-500 million people being infected. It is a parasitic disease caused by Plasmodium falciparum and Plasmodium vivax (Paul et al., 2013). According to the world malaria report, approximately 219 million malaria cases are reported each year (WHO, 2012). In spite of several control measures, there has been very scarce improvement in the control of the disease, which leads to both economic and human fatalities (Shankar et al., 2012). It is one of the major devastating problems in NorthEast India and this region was also labeled as 'malaria zone' by the Center of Excellence in Disaster Management and Humanitarian Assistance (COEDMHA) and Pacific Disaster Management Information Network (PDMIN) survey team within their report during 2005. Moreover, World Health Organization (WHO) classifies this region as a highly endemic area for malaria (Korenromp, 2004).

Since immemorial times, the use and knowledge of herbal medicines was a treasured possession and prominent culture in rural India. This treasured medico-lore is then passed down over many generations chiefly by oral transmission (Katuura et al., 2007). Many tribal communities worldwide use herbs to monitor different ailments, many of which are reported to be exceptionally effective and very promising (Shankar et al.,
2012). North East India represents an extremely unique ecosystem treasured with medicinal plant wealth and rich tribal assortment related with folk knowledge, including traditional medicinal practices.

A huge number of plant species has been reported to be used in ethno-phytotherapy treatment of malaria worldwide. The North Eastern region of India alone uses at least 68 plants, belonging to 33 families, to treat malaria (Shankar et al., 2012). The success of the quinine as an antimalarial drug, and the synthesis of artemisinin, the most potent antimalarial drug from plant sources, has encouraged the study of plants as antimalarial agents (Saxena et al., 2003). Although several ethno-medicinal survey of North Eastern India has been done by different researchers, the utility of thoroughgoing traditional phytotherapy by ethnic communities is still unexplored (Chakraborty et al., 2012).

The present study was conducted to accumulate the knowledge on traditional uses of therapeutic plants for the treatment of malaria as fulfilled by the ethnic communities inhabiting Jonai, sub-division of Assam in North East India.

\section{Materials and Methods}

\section{Study area}

The extensive field survey was carried out in Jonai, an Eastern subdivision of Dhemaji district, Assam, located at 


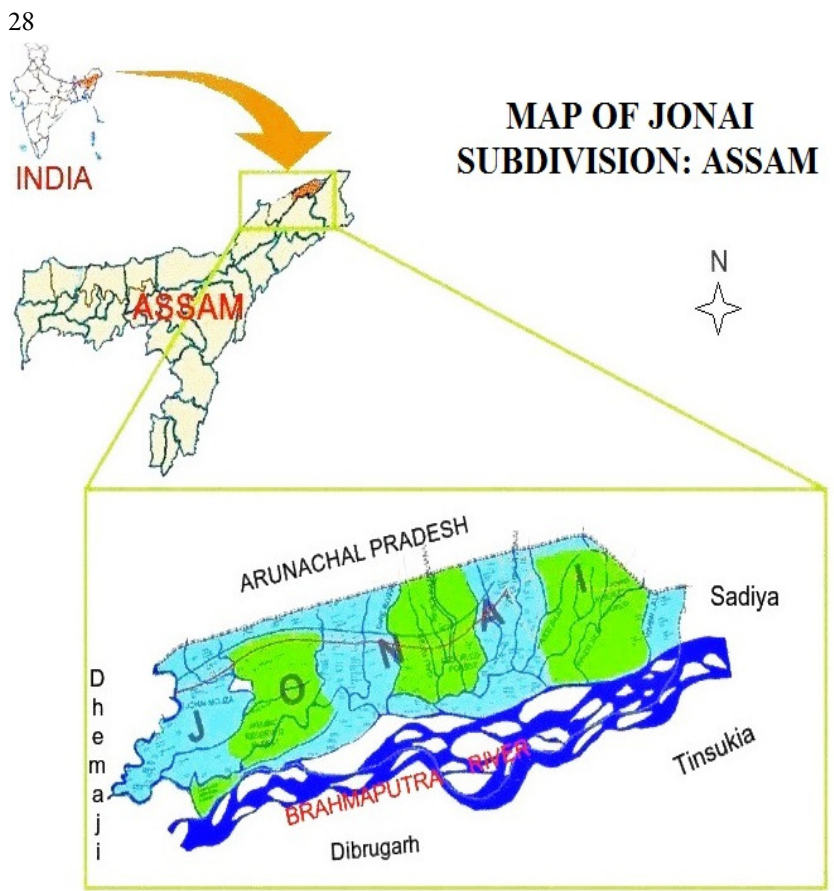

Fig. 1. Map of the study area

$27^{\circ} 83^{\prime} \mathrm{N}$ Latitude to $95^{\circ} 22^{\prime} \mathrm{E}$ Longitude (Fig. 1). The subdivision covers a total geographical area of $1,112 \mathrm{~km}^{2}$; it is surrounded by Sipiya River and Sadiya subdivision of Tinsukia district at the East, Simen River to the West, the state of Arunachal Pradesh to the North and the mighty Brahmaputra River to the South. Jonai is inhabited mostly by the Mishing community along with Nepalese and Assamese.

\section{Ethnobotanical data collection}

Field studies were conducted following Martin (1995) ethnobotanical techniques of data and voucher specimen collection. Ethno-medicinal data has been collected through Participatory Rural Appraisal (PRA), based on personal interaction with the indigenous population and practical observation in the field survey (Chambers, 1994). A total of 80 informants, mostly traditional herbalist and village elders, were approached based on their knowledge, skills and practices in folk medicinal plant application. Semi-structured questionnaires were designed for obtaining objective information, mainly focusing on information regarding the uses of plants to treat malaria and other ailments of human beings, local names of the plants, growth forms, parts used, modes of preparation and administration of the herbal remedies.

The specimens were identified according to "The Plant List" and voucher specimens were deposited in the unit of Plant Systematic and Ethnobotany Laboratory, Rajiv Gandhi University, Rono Hills, Arunachal Pradesh.

\section{Data analysis}

The following quantitative and qualitative ethnobotanical methods were used for data analysis. Fidelity level (FL) was calculated to know the percentage of informants claiming the use of a plant species for the same major purpose. It was calculated for reporting ailments as:

$$
\mathrm{FL}(\%)=\mathrm{Np} / \mathrm{N} X 100
$$

The $\mathrm{Np}$ is the total number of informants that are claiming to use a plant species to treat malaria and $\mathrm{N}$ is the number of informants that use the plants as a medicine to treat any disease (Alexiades, 1996).

The percentage of respondents having knowledge (PRK) regarding the use of a species (frequency of citation) in the treatment of malaria was estimated using the formula:

$\mathrm{PRK}(\%)=\mathrm{Np} / \mathrm{Nt} \times 100$

The $\mathrm{Np}$ is the total number of informants that are claiming to use a plant species to treat malaria and $\mathrm{Nt}$ is the total number of individuals interviewed (Yaniv et al., 1987).

Preference ranking (PR) method was used to rank plants according to their effectiveness within malaria treatment (Martin, 1995). The rank is given an integer (1,2 or 3), with the most effective plants assigned a value of 3 .

\section{Results}

\section{Documentation of indigenous ethno-medicinal knowledge}

The study revealed 16 plant species belonging to 13 taxonomic families which were commonly used by most of the tribal communities and traditional healers against malaria. The most prominent families were Lamiaceae and Piperaceae with 2 species each, while the other families, with single species, were Amarnanthaceae, Amiaceae, Amaryllidaceae, Apocynaceae, Acanthaceae, Asteraceae, Meliaceae, Caricaceae, Bignoniaceae, Euphorbiaceae, Poaceae and Combretaceae. Most of the plants used for malaria treatment are collected directly from wild, while few of them were also reported to be cultivated.

The documented antimalarial plant species can be categorized into five different groups, based on their conservation status: cultivated and abundant (CA), cultivated and frequent $(\mathrm{CF})$, wild and abundant (WA), wild and frequent (WF), wild and rare (WR) (Fig. 2). It can be concluded in this regard that out of the 16 species, 15 are either abundantly or frequently, found near forests or even cultivated in home gardens, while Piper longum was recorded as wild and rare in terms of its accessibility.

On behalf of each plant species, the authors have provided the herbarium voucher number, botanical name, family, vernacular name, life form, plant part used, method of preparation and mode of administration in Table 1.

\section{Life forms and plantpartsused}

Herbs were the primary source of folk medicine (44\%) followed by trees (25\%), shrubs (19\%) and climbers (12\%) (Fig. 3). Among the different plant parts used, the roots (29\%) were most frequently used for the preparation of medicine, either



Fig. 2. Conservation status of antimalarial plants found in Jonai, Assam 
Table 1. Antimalarial plants used in Jonai, Assam, India

\begin{tabular}{|c|c|c|c|c|c|}
\hline Plants (Voucher No.) & Family (Habit) & Local name & $\begin{array}{l}\text { Conservation } \\
\text { status }\end{array}$ & $\begin{array}{l}\text { Part } \\
\text { used }\end{array}$ & Mode of preparation and administration \\
\hline $\begin{array}{l}\text { Achyranthes aspera } \mathrm{L} \text {. } \\
\text { (JT/451/2014) }\end{array}$ & $\begin{array}{l}\text { Amaranthaceae } \\
(\mathrm{H})\end{array}$ & Apamarga, Datiun & WA & $\mathrm{Rt}, \mathrm{St}$ & $\begin{array}{l}\text { Decoction made of root and stem is taken } \\
\text { orally thrice a day. }\end{array}$ \\
\hline $\begin{array}{l}\text { Ajuga integrifolia Buch.-Ham. } \\
\text { (JT/477/2014) }\end{array}$ & $\begin{array}{l}\text { Lamiaceae } \\
(\mathrm{H})\end{array}$ & Nilakantha & $\mathrm{CF}$ & Rt & $\begin{array}{l}\text { One cup of root decoction assorted with } \\
\text { honey and administered orally after } \\
\text { breakfast. }\end{array}$ \\
\hline $\begin{array}{l}\text { Allium sativum L. } \\
\text { (JT/469/2014) }\end{array}$ & $\begin{array}{l}\text { Amaryllidaceae } \\
(\mathrm{H})\end{array}$ & Aduwa & $\mathrm{CA}$ & Fr & $\begin{array}{l}\text { Rhizomes are crushed into paste and boiled } \\
\text { in water for } 1 \text { hour. Decoction is } \\
\text { supplemented with sugar and taken orally } \\
\text { twice a day. }\end{array}$ \\
\hline $\begin{array}{l}\text { Alstonia scholaris (L.) R. } \\
\text { Br.(JT/476/2014) }\end{array}$ & $\begin{array}{l}\text { Apocynaceae } \\
(\mathrm{T})\end{array}$ & Chhatiwan & WF & $\mathrm{Br}$ & $\begin{array}{l}\text { The small piece of bark is boiled in } 100 \mathrm{ml} \text { of } \\
\text { water for half an hour. Approximately } 20 \mathrm{ml} \\
\text { of filtrate is recommended orally, twice a day } \\
\text { for } 2 \text { weeks. }\end{array}$ \\
\hline $\begin{array}{l}\text { Andrographis paniculata } \\
\text { (Burm.f.) Nees (JT/450/2014) }\end{array}$ & $\begin{array}{l}\text { Acanthaceae } \\
(\mathrm{H})\end{array}$ & Chiraito & $\mathrm{CF}$ & Rt & $\begin{array}{l}\text { Honey is mixed with root decoction. } 2 \\
\text { teaspoonful of the mixture is advised to be } \\
\text { taken orally twice a day for at least } 10 \text { days. }\end{array}$ \\
\hline $\begin{array}{l}\text { Artemisia indica Willd. } \\
\text { (JT/453/2014) }\end{array}$ & $\begin{array}{l}\text { Asteraceae } \\
(\mathrm{H})\end{array}$ & Titepati & WA & Rt & $\begin{array}{l}\text { Low concentration root decoction is mixed } \\
\text { with honey. It is recommended to be taken } \\
\text { once a day for } 10 \text { days. }\end{array}$ \\
\hline $\begin{array}{l}\text { Azadirachta indica A .Juss. } \\
\text { (JT/475/2014) }\end{array}$ & $\begin{array}{l}\text { Meliaceae } \\
(\mathrm{T})\end{array}$ & Neem & $\mathrm{CF}$ & Lf & $\begin{array}{l}\text { Leaves are pounded into small globules } \\
\text { (approx. } 5 \mathrm{~g} \text { each) and mixed in } 50 \mathrm{ml} \text { of } \\
\text { water prior to oral administration. Globules } \\
\text { recommended twice a day for } 15 \text { days. } \\
\text { Sometimes the globules are also dried in sun } \\
\text { to obtain powder. }\end{array}$ \\
\hline Carica papaya L. (JT/470/2014) & $\begin{array}{l}\text { Caricaceae } \\
(S)\end{array}$ & Mewa & $\mathrm{CA}$ & $\mathrm{Fl}$ & $\begin{array}{l}\text { Flowers (approx. } 20 \mathrm{~g} \text { ) are boiled in } 300 \mathrm{ml} \\
\text { water and decoction is taken twice a day. }\end{array}$ \\
\hline $\begin{array}{l}\text { Clerodendrum glandulosum Lin } \\
\text { dl. (JT/471/2014) }\end{array}$ & $\begin{array}{l}\text { Lamiaceae } \\
(S)\end{array}$ & Pakkom & $\mathrm{CF}$ & Lf & $\begin{array}{l}\text { Leaves are boiled in water to make a } \\
\text { decoction and taken twice a day. }\end{array}$ \\
\hline $\begin{array}{l}\text { Ocimum tenuiflorum } \mathrm{L} . \\
\text { (JT/474/2014) }\end{array}$ & $\begin{array}{l}\text { Lamiaceae } \\
(\mathrm{H})\end{array}$ & Tulasi & $\mathrm{CF}$ & Lf, Rt & $\begin{array}{l}\text { Leaf and root decoction is supplemented } \\
\text { with honey. It is recommended twice a day } \\
\text { before meals. }\end{array}$ \\
\hline $\begin{array}{l}\text { Oroxylum indicum L. } \\
\operatorname{Kurz}(J T / 466 / 2014)\end{array}$ & $\begin{array}{l}\text { Bignoniaceae } \\
(\mathrm{T})\end{array}$ & Totela & WA & $\mathrm{Fl}, \mathrm{Br}$ & $\begin{array}{l}\text { Flower and bark (approx. } 10 \mathrm{~g} \text { ) are dissolved } \\
\text { in } 100 \mathrm{ml} \text { of water and decoction is } \\
\text { consumed thrice a day. }\end{array}$ \\
\hline Piper longum L. (JT/452/2014) & $\begin{array}{l}\text { Piperaceae } \\
\text { (C) }\end{array}$ & Pipla & WR & $\mathrm{Fr}, \mathrm{Rt}$ & $\begin{array}{l}\text { Few pieces of fruit and root are grounded } \\
\text { into powdered form and boiled in a liter of } \\
\text { water until the volume is reduced up to } 500 \\
\text { ml. } 2-3 \text { spoons of mixture are prescribed } \\
\text { orally before meals. }\end{array}$ \\
\hline Piper nigrum L. (JT/468/2014) & $\begin{array}{l}\text { Piperaceae } \\
\text { (C) }\end{array}$ & Marich & WA & $\mathrm{Sd}$ & $\begin{array}{l}5 \mathrm{~g} \text { of seed powder are mixed in } 10 \mathrm{ml} \text { of hot } \\
\text { water along with honey and taken orally } \\
\text { thrice a day. }\end{array}$ \\
\hline $\begin{array}{l}\text { Ricinus communis } \mathrm{L} \text {. } \\
\text { (JT/473/2014) }\end{array}$ & $\begin{array}{l}\text { Euphorbiaceae } \\
(\mathrm{H})\end{array}$ & Aeri & WA & Lf & $\begin{array}{l}\text { Leaf decoction supplemented with sugar is } \\
\text { administered orally once a day. }\end{array}$ \\
\hline $\begin{array}{l}\text { Saccharum officinarum L. } \\
\text { (JT/467/2014) }\end{array}$ & $\begin{array}{l}\text { Poaceae } \\
(S)\end{array}$ & Ukhu, Kuwer & $\mathrm{CA}$ & St & $\begin{array}{l}\text { A glass of juice extract of stem portion is } \\
\text { taken twice a day after meals. }\end{array}$ \\
\hline $\begin{array}{l}\text { Terminalia chebula Retz. } \\
\text { (JT/472/2014) }\end{array}$ & $\begin{array}{l}\text { Combretaceae } \\
(\mathrm{T})\end{array}$ & Harro & WF & $\mathrm{Fr}, \mathrm{Br}$ & $\begin{array}{l}\text { 5-10 g of fruit and bark are cut into small } \\
\text { pieces and dissolved in } 100 \mathrm{ml} \text { of water. The } \\
\text { decoction is taken orally before meal. }\end{array}$ \\
\hline
\end{tabular}

Note: cultivated and abundant (CA), cultivated and frequent (CF), wild and abundant (WA), wild and frequent (WF), wild and rare (WR); Fruit (Fr),

Flower (Fl), Leaf (Lf), Seed (Sd), Bark(Br), Stem (St), Root (Rt)

exclusively or mixed with other plants' organs. Roots were followed in the preparation mode by leaves (19\%), fruit and bark (14\% each), flowers (10\%), stems (9\%) and seeds (5\%) (Fig. 4).

Method of preparation, mode of administration and prescription of dosage

Herbal formulation of antimalarial plants varies from plant to plant (Table 1). The preparation and utilization of plant parts were grouped into four categories. Most commonly used method of preparation was decoction
(52.94\%) followed by juice (23.53\%), powder $(17.65 \%)$ and raw (5.88\%) (Fig. 5). The decoction was obtained by boiling the plant parts (evenly chopped or grounded parts) in water until the volume of the water reduced to the required amount. The paste was prepared by grinding the fresh or dried plant parts with water as solvent. The powder was generally prepared by the grinding of shade dried plant or raw plant parts.

Some of the herbal preparations were recorded to be supplemented with honey and sugar. According to the local 
30

Table 2. Fidelity level (FL), PPK (Percentage of respondents who have knowledge) and PR (Preference ranking) of species used to treat malaria in Jonai subdivision, Assam (Total informants $=80$ )

\begin{tabular}{|c|c|c|c|c|c|}
\hline Botanical name & Ip & $\mathrm{Iu}$ & FL $(\%)$ & PRK (\%) & PR \\
\hline Achyranthes aspera $\mathrm{L}$. & 32 & 39 & 82 & 40 & 1 \\
\hline Ajuga integrifolia Buch.-Ham. & 22 & 21 & 100 & 26 & 2 \\
\hline Allium sativum $\mathrm{L}$. & 29 & 72 & 40 & 36 & 3 \\
\hline Alstonia scholaris (L.) R. Br. & 42 & 48 & 88 & 53 & 1 \\
\hline Andrographis paniculata (Burm.f.) Nees & 26 & 34 & 76 & 33 & 2 \\
\hline Artemisia indica Willd. & 31 & 41 & 76 & 39 & 3 \\
\hline Azadirachta indica A. Juss. & 15 & 67 & 22 & 19 & 3 \\
\hline Carica papaya L. & 18 & 26 & 69 & 23 & 3 \\
\hline Clerodendrum glandulosumLindl. & 9 & 23 & 39 & 11 & 3 \\
\hline Ocimum tenuiflorum $\mathrm{L}$. & 18 & 25 & 72 & 23 & 3 \\
\hline Oroxylum indicum (L.) Kurz & 24 & 28 & 86 & 30 & 3 \\
\hline Piper longum L. & 17 & 24 & 71 & 21 & 3 \\
\hline Piper nigrum L. & 24 & 57 & 42 & 30 & 3 \\
\hline Ricinus communis $\mathrm{L}$. & 30 & 32 & 94 & 38 & 1 \\
\hline Saccharum officinarum $\mathrm{L}$. & 11 & 16 & 69 & 14 & 2 \\
\hline Terminalia chebula Retz. & 15 & 34 & 44 & 19 & 2 \\
\hline
\end{tabular}

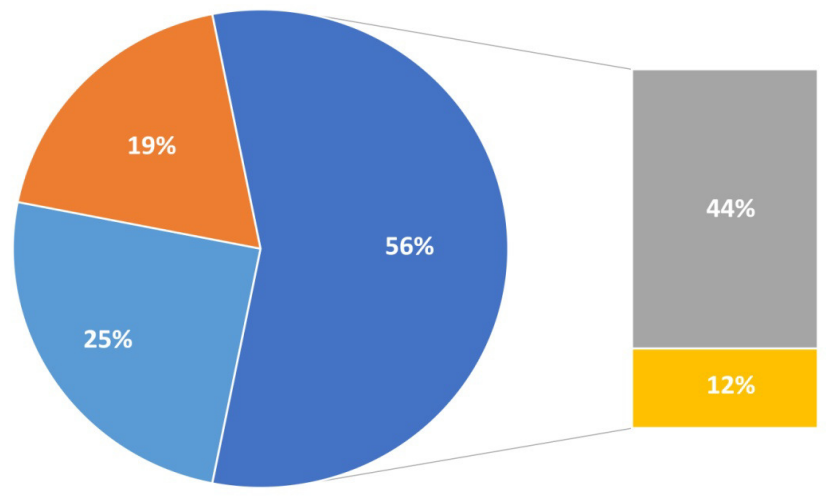

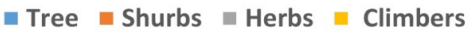

Fig. 3. Life form of reported common medicinal species

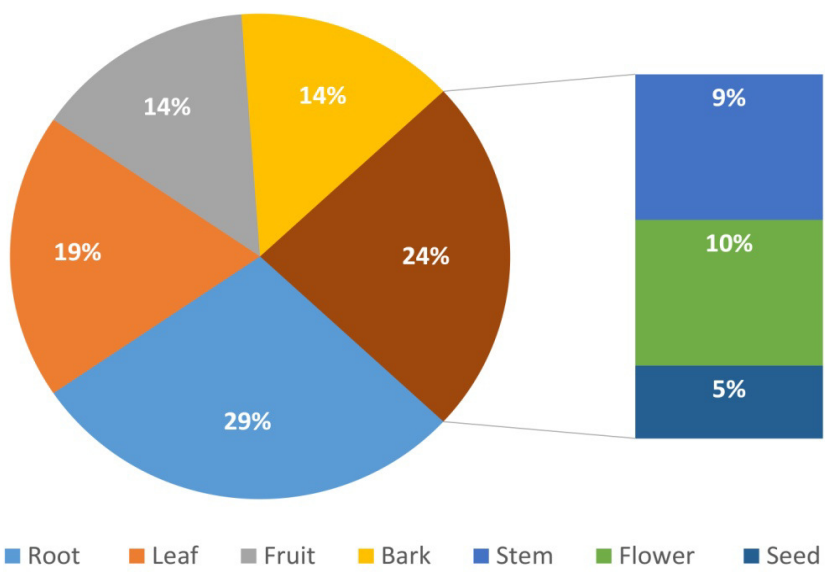

Fig. 4. Plants parts used for the preparation of medicine

informants, the prime purpose of these supplements was to counteract the bitterness and make the overall preparation more palatable as well as for improving the acceptability. All the preparations were orally administered and prescribed for once a day, twice a day or thrice a day, depending on the proficiency of the prepared dosage (Table 1). These plants

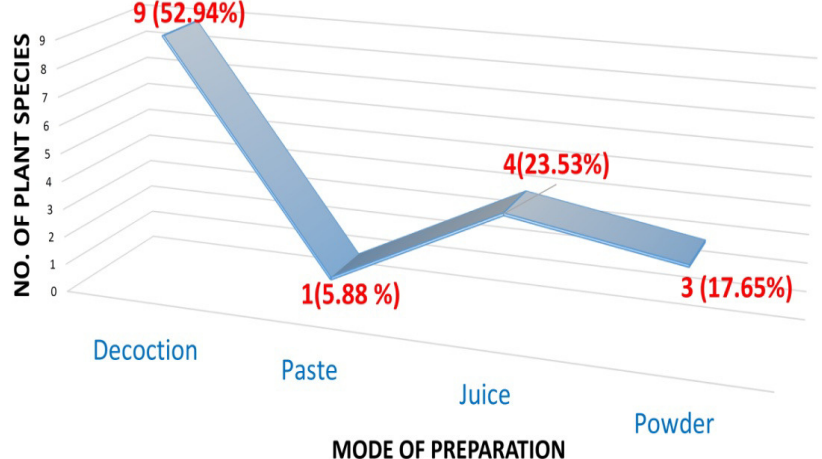

Fig. 5. Mode of plants parts utilization within the preparation of medicine

were used in most of the household owing to the availability and easy collection from wild. Herbal self-medication practices were always the first choice of treatment among the locality, unless the patients grab hold of severe fever. The native healers opined that those herbal drugs prescribed were devoid of any side effects. There was a serious lack of any information regarding treatment standardization or the procedure. Thus, the quality could vary greatly among the prescriptions.

Investigation of qualitative and quantitative ethnopharmacological parameters

Following quantitative and qualitative ethnobotanical methods to determine culturally and ethnomedically important species of this region, fidelity level (FL) of plants has been analyzed based on the number of informants (Table 2). FL value of Clerodendrum glandulosum was reported to be the least, with only 9 informants out of total 80 using it for malaria treatment (11.25\%). Even so, the value was more than $10 \%$, therefore all the species were considered for the final comparison. The analysis revealed highest FL value for Ajuga integrifolia (100\%) followed by Ricinus communis (94\%), Alstonia scholaris (88\%), Oroxylum indicum (86\%) and Achyranthes aspera (82\%). The maximum fidelity level indicated $100 \%$ for Ajuga integrifolia, thus the species 
represents a common choice among all interviewed informants for treating malaria and this could be a clue of the healing potential of the species (Ayyanar and Ignacimuthu, 2011).

The percentage of respondents who have knowledge (PRK) about anti-malarial plants unveiled $A$. scholaris (53\%) as the most commonly known antimalarial plant within the study region, while some other commonly known plants were Achyranthes aspera (40\%), Azadirachta indiaca (39\%), Ricinus communis (38\%) and Allium sativum (36\%) (Table 2).

Preference ranking (PR) unveiled 9 species to be very effective against malarial parasite. These plants included Allium sativum, Artemisia indica, Azadirachta indica, Carica papaya, Clerodendrum glandulosum, Ocimum tenuiflorum, Oroxylum indicum, Piper longum and Piper nigrum (Table 2).

\section{Discussion}

Dependency on these plants was primarily due to their safety, effectiveness, cultural preferences, affordability and their abundance. It is imperatively vital that the entire ethnoflora of this region to be documented, as this information could assist in identifying of conservation strategies for target species, followed by supporting the health and economy of the entire community (Asase et al., 2005). The therapeutic activity of medicinal plants has made an outstanding contribution, but then the traditional knowledge on medicinal plants and their utilization are prone to disappear because of insufficient written records and rapid modernization. However, commencement of ethnobotanical surveys and compilation of information regarding medicinal plants within a systemic manner can pave new thresholds in research and developmental areas.

It was observed that the contribution of herbaceous species in the context of antimalarial effect was at maximum, while roots were the most frequently used plant parts for the preparation of herbal drug against malaria. Similar findings were also reported by Paul et al. (2013) among Bodo people of Manas Biosphere reserve, Assam; Ibrahima et al. (2012) while studying Nigerian Medicinal Plants; Katuura et al. (2007) while studying traditional antimalarial plants of Mbarara District, Western Uganda; Madureira et al. (2002) in S. Tomé and Principe islands; Asase et al. (2005) among some Ghanaian anti-malarial plants and Bora et al. (2007) in North East India. On the other hand, many researchers observed leaves as the prime ethnomedicinal ingredient against many ailments (Mahishi et al., 2005; Srithi et al., 2009; Giday et al., 2010; Ayyanar and Ignacimuthu, 2011). The reason for their extensive utilization is that leaves can be easily collected compared with the underground parts, flowers or fruits etc. (Giday et al., 2009). Similar state of plant uses was also reported by Asase et al. (2005) in Upper West Region of Ghana. Yet, insufficient data or written records on the clinical utility of the traditional drugs in this region are some of the major hurdles.

Owing to the crucial role played by plant derived compounds within drug discovery, isolation of new bioactive compounds, based on the knowledge of the traditional use of medicinal plants, would be a very promising approach in the near future (Tushar et al., 2010). However, a suitable approach is needed to use these agents as templates for scheming new derivatives with enhanced properties (Saxena et al., 2003). There is a high possibility that therapeutically active antimalarial compounds can be isolated from these species, which can play a crucial role in the advancement of improved antimalarial drugs. Nonetheless, further profound analysis and controlled clinical trials are essential before these traditional remedies can be recommended on a large scale.

\section{Conclusions}

The current work was a preliminary effort to quantify the information on antimalarial plants among the Mishing indigenous tribal communities of Jonai, which revealed the competency of traditional medicines in treatment of malaria. The study also provides better option for the selection of widely used medicinal plants, for searching bioactive compounds. An accurate knowledge on the plants medicinal properties is held by few individuals, including traditional healers. Thus, there is an urgent need for detailed investigation of the knowledge held by tribal communities before they cease to exist. The efficacy and safety of all the reported ethnomedicinal plants needs to be evaluated further, using phytochemical and pharmacological methods. Plants with high fidelity level and use report should be given priority to carry out bioassay and toxicity studies. From the current study, it might be suggested that Ajuga integrifolia, Achyranthes aspera, Alstonia scholaris, Artemisia indica, Oroxylum indicum and Ricinus communis are promising species that should be taken into account for further pharmacological studies. The results indicated that this species may be used for the development of novel, economical, effective and ecofriendly herbal formulations for healthcare management.

\section{Acknowledgement}

The authors acknowledge traditional healers and indigenous tribal communities of Jonai, Assam, for their contribution and valuable information for the current research.

\section{References}

Alexiades MN (1996). Selected guidelines for ethnobotanical research: A field manual. New York: The New York Botanical Garden pp 99-133.

Asase A, Oteng-Yeboah AA, Odamtten GT, Simmonds MSJ (2005). Ethnobotanical study of some Ghanaian anti-malarial plants. Journal of Ethnopharmacology 99(2):273-279.

Ayyanar M, Ignacimuthu S (2011). Ethnobotanical survey of medicinal plants commonly used by Kani tribals in Tirunelveli hills of Western Ghats, India. Journal of Ethnopharmacology 134(3):851-864.

Bora U, Sahu A, Saikia AP, Ryakala VK, Goswami P (2007). Medicinal plants used by the people of Northeast India for curing malaria. Phytotherapy Research 21(8):800-804. 
32

Chakraborty R, Deb B, Devanna N, Sen S (2012). North-East India an ethnic store house of unexplored medicinal plants. Journal of Natural Product and Plant Resources 2(1):143-152.

Chambers R (1994). Participatory rural appraisal (PRA): Analysis of experience. World Development 22(9):1253-1268.

do Céu de Madureira M, Martins AP, Gomes M, Paiva J, Proença da Cunha A, do Rosário V (2002). Antimalarial activity of medicinal plants used in traditional medicine in S. Tomé and Principe islands. Journal of Ethnopharmacology 81(1):23-29.

Giday M, Asfaw Z, Woldu Z (2009). Medicinal plants of the Meinit ethnic group of Ethiopia: an ethnobotanical study. Journal of Ethnopharmacology 124(3):513-521.

Giday M, Asfaw Z, Woldu Z (2010). Ethnomedicinal study of plants used by Sheko ethnic group of Ethiopia. Journal of Ethnopharmacology 132(1):75-85.

Ibrahima HA, Imama IA, Bellob AM, Umara U, Muhammada S, Abdullahi SA (2012). The potential of Nigerian medicinal plants as antimalarial agent: a review. International Journal of Science and Technology 2(8):600-605.

Katuura E, Waako P, Ogwal-Okeng J, Bukenya-Ziraba R (2007). Traditional treatment of malaria in Mbarara District, western Uganda. African Journal of Ecology 45(1):48-51.

Korenromp E (2004). World malaria report: Roll Back Malaria. World Health Organization, Geneva.

Mahishi P, Srinivasa BH, Shivanna MB (2005). Medicinal plant wealth of local communities in some villages in Shimoga District of Karnataka, India. Journal of Ethnopharmacology 98(3):307312.
Martin G (1995). Ethnobotany - A manual of methods. London: Earthscan Publishers Limited.

Paul S, Devi N, Sarma GC (2013). Ethnobotanical utilization of some medicinal plants by Bodo people of Manas biosphere reserve in the treatment of malaria. International Research Journal of Pharmacy 4(6):102-105.

Saxena S, Pant N, Jain DC, Bhakuni RS (2003). Antimalarial agents from plant sources, Current Science 85(9):1314-1329.

Shankar R, Deb S, Sharma BK (2012). Antimalarial plants of northeast India: an overview. Journal of Ayurveda and Integrative 3(1):10-16.

Srithi K, Balslev H, Wangpakapattanawong P, Srisanga P, Trisonthi C (2009). Medicinal plant knowledge and its erosion among the Mien (Yao) in northern Thailand. Journal of Ethnopharmacology 123(2):335-342.

Tushar, Basak S, Sarma GC, Rangan L (2010). Ethnomedical uses of Zingiberaceous plants of Northeast India. Journal of Ethnopharmacology 132(1):286-296.

Yaniv Z, Dafni A, Friedman J, Palewitch D (1987). Plants used for the treatment of diabetes in Israel. Journal of Ethnopharmacology $19(2): 145-151$.

WHO (2012). World malaria report 2012. Geneva, Switzerland: World Health Organization. 